\title{
NIOR NATURALISTS
}

's April already, they ought to be ," Phillipa Fox sounded worried. She trotting across a big bare pasture. Magpie was flying above her head.

o you see them Mark?" she asked ously looking up.

Who? Do I see who?" Mark asked.

u know, Rusty and his wife. They're ginous Hawks, big pretty hawks like Golden Eagles," explained Phillipa. re's not many Ferruginous Hawks id. They need lots of wide open and people haven't left that much e, but you remember Rusty don't He and his wife have been back in asture every year for ages."

course I remember Rusty. What do hink I am, anyway, a scatter brain?" demanded.

ell if you're not a scatter brain, how you forgot we're looking for them?" pa asked.

k didn't answer, he just pretended been looking all along, and flew $r$ in tight circles to prove it. Phillipa's drew circles in the air as she tried to him.

pe, nope, I can't see them there. re not there, not anywhere there" he and added, sounding surprised, "I ven see where their nest is, and it mean it isn't even there. Even the isn't there either. It's there, but it isn't there, you know, I mean it's not up, and they're not there here or here even."
Phillipa shook herself all over hard, "Whew Mark, you fly in circles 'til I'm dizzy, but your words are even worse. I'm going to see for myself."

She laid back her ears, and with her bushy tail straight behind her, she galloped across the short grass.

Mark beat her to the spot, and perched there yelling. "See, I told you."

By the broken down buildings of an old homestead, the gnarled grey trunk and tangled branches of a big tree lay on the ground. Phillipa sniffed at the heap of dust and dry sticks that was all that was left of Rusty's nest from the years before. She looked sad.

"Those cows rubbed it down; they like a good rubdown. It's not their fault if they rubbed it right down," Mark babbled.

Mark was right. Cattle had used the tree to rub up against, and spent so much time there that their hard hooves had finally dug a trench around it, and they'd rubbed the tree right over.

"No wonder Rusty's not here," Phillipa said. "He's got no where left to nest. There isn't a single other tree here."

"Were y'all lookin' for me?" said a harsh voice right behind them. Both animals spun round to see a huge hawk perched on a corner of the tumbledown barn.

"Rusty! You're back! But where's your nest?" Phillipa asked.

"I guess I don't mind lettin' y'all know," Rusty said. Spending winters in the southwestern U.S.A. had given him a bit of a 
drawl. "Emma and me was mighty startled at findin' our favorite nestin' tree down, but I know my great grand-pappy used to nest on cliffs, or the sides of steep coulees. Emma and I thought maybe we could find somethin' like that."

His huge wings shoved him up into the air, and he yelled, "Kree-a, kree-a, y'all come and see!"

After a mile of fast trotting Phillipa finally got to where she'd seen Rusty and Mark come down.

"Hey, this is no coulee or cliff!" she protested.

Rusty was perched part way up what looked like a telephone pole, on a big shelf. His wife Emma was there, too. She was a lot darker than Rusty, almost black.

"Ha ha haha!" yelled Mark from the top of the pole. "They fooled you, ha ha hahaha! Phillipa the fooled fox."

\section{"I guess you did," Phillipa agreed.}

"This ain't a cliff or a tree, but we was mighty glad to find it," Rusty drawled.

"That's right" Emma said. "There wasn't any coulees to speak of in this pasture at all, and me and Rusty didn't have in mind to move. This pasture's been a fine place to raise young'uns. They's lots of wide open space, and lots of gophers."

"Speakin' of gophers," interrupted Rusty, "l'd better get to work and russell us up some dinner. Bye Phillipa, bye Mark, it was nice seein' $y^{\prime}$ all agin."

"Isn't he magnificent?" asked Phillipa looking up as the huge hawk rose in lazy circles.

"Magnificent, me?" said Mark, "Magnificent magpie, Mark the magnificent magpie. That's me alright."
"Silly, I wasn't talking about you à Phillipa, and both she and Emma la it at him. Mark flew off squawking i indignation.

"It's great to have you and Rusty Emma," said Phillipa, "but I sure w d where this nest pole thing came $)$ Maybe we'll never know."

Junior Naturalists, try a little det i work and look in the December $)$ Blue Jay for a clue, or ask Dr. C. di Houston $[863$ University Drive ic katoon, Saskatchewan S7N 0J: Karen Rispin, Box 507, Dalmeny ;á katchewan. SOK 1 E0

\section{EDITOR'S NOTE:}

Due to the small number of members now belonging to the and to the lack of response to the section, the Board of Directo decided to provide our junior me with a magazine that is more su their age level. The SNHS has donation to Kid Proof, an award- $\mathrm{v}$ Saskatchewan magazine for $s$ children produced by three $\mathrm{R}$ women, in return for the addition names of our junior members to i ing list. In addition to Blue Jay our members will receive Kid Proof. A is encouraged to submit nature art the magazine in order to incre natural history content. 